\title{
The multidisciplinary team in sports: a narrative review
}

\author{
A equipe multidisciplinar no esporte: uma revisão narrativa \\ El equipo multidisciplinario en el deporte: una revisión narrativa
}

Ramiro Marques Inchauspe ${ }^{1 *}$, Pablo Morales Barbian², Fabrício Luis Pereira Santos ${ }^{3}$, Marcelo Schlling da Silva ${ }^{4}$, Caroline Talhietti Rabaioli ${ }^{5}$.

\begin{abstract}
Objective: The multidisciplinary team in sport is justified by the growing pursuit of higher performance and performance and many variables are involved in this context, recovery and rest, training, emotional control, examinations and nutritional control, factors need specific knowledge from professionals in different areas, such as physical therapists, psychologists, doctors, nutritionists and the physical education professional. Methods: In this context, using a literature review, the purpose of this paper is to discuss the contributions of professionals from different areas in the preparation of athletes, briefly referencing their attributions. Results: The importance of a multidisciplinary team in the training of athletes becomes evident so that there can be an integration of different professionals in search of a single goal. Final considerations: Through this relevant approach in the relationship of these professionals will allow an elucidation of the aspects inherent in improving performance, thus providing the maintenance of the performance of teams trained by multidisciplinary teams.
\end{abstract}

Key words: Multidisciplinary, Sports, Performance Evaluation.

\section{RESUMO}

Objetivo: A equipe multidisciplinar no esporte justifica-se pela busca crescente de maior desempenho e desempenho e muitas variáveis estão envolvidas nesse contexto, recuperação e descanso, treinamento, controle emocional, exames e controle nutricional, fatores que necessitam de conhecimentos específicos de profissionais de diversas áreas, como como fisioterapeutas, psicólogos, médicos, nutricionistas e o profissional de educação física. Métodos: Nesse contexto, utilizando-se de uma revisão de literatura, o presente tem por finalidade discorrer sobre as contribuições de profissionais de diferentes áreas no preparo de atletas, referenciando de maneira sucinta as suas atribuições. Resultados: A importância de uma equipe multidisciplinar no treinamento dos atletas torna-se evidente de modo que possa ocorrer uma integração de diferentes profissionais em busca de um único objetivo. Considerações finais: Por meio dessa relevante aproximação na relação desses profissionais é que se permitirá uma elucidação dos aspectos inerentes à melhoria do rendimento, proporcionando, dessa forma, a manutenção da performance de equipes treinadas por equipes multidisciplinares.

Palavras-chave: Multidisciplinar, Esportes, Avaliação do Rendimento.

\section{RESUMEN}

Objetivo: El equipo multidisciplinario en el deporte se justifica por la búsqueda creciente de un mayor rendimiento y rendimiento y muchas variables están involucradas en este contexto, recuperación y descanso, entrenamiento, control emocional, exámenes y control nutricional, los factores necesitan conocimiento específico de profesionales en diferentes áreas, como como fisioterapeutas, psicólogos, médicos, nutricionistas y profesionales de la educación física. Métodos: En este contexto, utilizando una revisión de la literatura, el propósito de este documento es discutir las contribuciones de profesionales de diferentes áreas

\footnotetext{
${ }^{1}$ Universidade Federal de Ciências da Saúde de Porto Alegre (UFCSPA), Porto Alegre-RS. *E-mail: ramiro.i@hotmail.com 2 Universidade Federal de Pelotas (UCPEL), Pelotas - RS.

${ }^{3}$ Faculdade SOGIPA, Porto Alegre - RS.

${ }^{4}$ Universidade FEEVALE, Novo Hamburgo - RS.

${ }^{5}$ Universidade do Sul de Santa Catarina (Unisul). Tubarão - SC.
} 
en la preparación de atletas, haciendo referencia brevemente a sus atribuciones. Resultados: La importancia de un equipo multidisciplinario en el entrenamiento de atletas se hace evidente para que pueda haber una integración de diferentes profesionales en busca de un solo objetivo. Consideraciones finales: A través de este enfoque relevante en la relación de estos profesionales permitirá una aclaración de los aspectos inherentes a la mejora del rendimiento, proporcionando así el mantenimiento del rendimiento de los equipos formados por equipos multidisciplinarios.

Palabras clave: Multidisciplinario, Deportes, Evaluación del rendimiento.

\section{INTRODUCTION}

Increasingly, the search for performance in professional sports has grown. Currently, professional sports teams have undergone some changes in the structure of human material that handled all aspects of athlete preparation. It is in this context that the multidisciplinary professional intervention is inserted. This multidisciplinary team is mainly composed of physical education professionals, physiotherapists, nutritionists, doctors, psychologists and others (NOCE F and SIMIM MA, 2009).

Until recently, the sports team's technical committees were basically formed by physical education professionals and retired athletes. However, with the constant search for performance and results, there was a broadening of the range of professionals involved in high performance, each attending their own specialty, contributing to the construction of results (BRANDT R, et al., 2014).

Guimarães GV and Ciolac EG (2004, p. 660) state that in order to maximize the benefits and safety of regular physical activity, an individualized and planned prescription of physical exercise according to the goal expected (cardiovascular, strength, muscular endurance and joint flexibility) is required. Thus, objectives, needs, initial abilities, patient's medical history and associated diseases should be previously considered

Thus, the articulation of knowledge between disciplines is important for better performance, as this integration promotes the understanding of the emotions and behaviors of the subjects involved in competitive practice. Besides allowing a technical improvement of the athletes, a team composed of several professionals from different areas allows an investigation of psychological phenomena that may decrease or increase the athlete's performance. (GOUVEIA MJM, 2001; EPIPHANIO EH, 1999).

In the meantime, the Physical Education Professional - being a sports-savy professional in all its aspects by being part of a multidisciplinary team, contributes to the athlete's performance effectively and effectively, because his knowledge related to sport enables to the professional, specific strategies individualizing the training according to the sport and the athlete. (VIEIRA TP e STUCCHI S, 2007).

Thus, the importance of integrating such professionals is emphasized, so that sports teams can rely on specialized work, contributing to the evolution of athletes and, consequently, the team as a whole. (LEONARDI TJ, et al. 2016). Thus, knowing how to act refers to allocating actions and procedures necessary for the desired results, which is why it is necessary to understand the athlete in its entirety. This work enters as a means of clarifying the relevance of the multidisciplinary team in the athlete's development process to achieve maximum performance, aiming at preserving their health. To achieve the objectives of the study, a literature review was then made, looking for different studies that addressed the effect of the performance of different professionals on the athlete's development, taking into consideration mainly physical therapists, sports psychologists and the Physical Education Professional.

\section{BIBLIOGRAPHICAL REVIEW}

\section{Papers research}

The present work deals with a bibliographical research. Prodanov CC and freitas EC (2013) conceptualize a bibliographic research is elaborated from existing material, that is, through books, scientific articles, journal publications, monographs, dissertations, internet, among others. 
This is a qualitative bibliographic research that emphasizes the performance of multidisciplinary teams and the importance of the Physical Education Professional inserted in this context, and was carried out by reading articles and journals published in the databases of the Virtual Library in Health (VHL); Scientific Electronic Library Online (SCIELO), Virtual Health Library of the Ministry of Health (BVSms) and electronic documents available in official governmental bases that are in accordance with the theme. This work had, as its general objective, to discuss the importance of integrating a multidisciplinary team in sports performance, and specific objectives, to present the contribution of the performance of Physical Education Professional, psychologists, physiotherapists, doctors and nutritionists in sports development; Show the performance benefit of athletes when accompanied by the Physical Education Professional, psychologist, physiotherapist, physician and nutritionist; Show the importance of the performance of professionals specialized in the preparation of athletes.

Inclusion criteria were publications in Portuguese language, complete and consistent with the theme of this study. Primarily the temporal delineation of the researched references contemplated the last eight years, and as to their origin: there are 42 references of scientific articles; 1 dissertation; 2 legislative references; 3 digital books. After reading all the pertinent publications, the present work started to be elaborated by topics, through the use of the selection of sources and the contents that were approached.

\section{Importance of the multidisciplinary team in sport}

The science of sports training highlights that improving an athlete's performance depends on the interaction of several factors. In this sense, the physical, technical, tactical and psychological factors are determining and intervening components for a good sports performance. It is also important to consider training and competition periods as guidelines for proper planning of sports training (NOCE F e SIMIM MA, 2009).

Thus, when planning, it is necessary to evaluate the multiple variables that affect the athlete's performance. The selection and training of high performance athletes requires different specialties so that individuals with physical and mental abilities consistent with what is required in high level competitions can be selected, hence the importance of the joint performance of the Physical Education Professional, medical psychologists, physiotherapists and others (BRANDT R, et al., 2014).

Based on this principle of joint action, Montagner PC and Silva CC (2003) discussed the selection of talents through soccer "sieves", placing this selection as a pedagogical and methodological process that requires sufficient time to teach, train and select individuals who They are superior in sport-specific qualities, performed for a few years and in several stages. The study showed the importance of mutual cooperation in multidisciplinary teams, each in its own field, but united - physical education teachers, coaches, physicians, nutritionists, psychologists and sports administrators - resulting in a selection system that guarantees renewals and increase in high level athletic performance.

Rose Junior D (2002) analyzed aspects related to stressful situations in high performance basketball and discussed the competitive factors that influence the results of competitors. In this study the author points out the importance of training composed of specialized professionals in order to provide tactics based on approaches to individual and situational factors. If these approaches were segmented as suggested by the author, we could correlate individual factors as being related to physical capacity, technical ability, injuries, fear of disappointing people and lack of rest. In turn, situational factors would be situations related to specific aspects of play, coaches, refereeing, teammates and improper training etc (MONTAGNER PC and SILVA CC, 2003).

Samulski D and Noce $F$ (2002) report that individual factors such as those arising from greater vulnerabilities related to results, and explain that in sport it is often observed that athletes are subjected to various types of pressure (twisting, result, time, charging of the coach and teammates, among others). In addition, their performance is related to their ability that require the athlete skill, precision and regularity. Listing these needs, previously described, Pujals C and Vieira LF (2008) show the importance and effectiveness of working with various professionals involved to obtain the maximum possible income. Thus, it is clear that the result in sports depends not only on physical training, but also on psychic training, capable of providing the athlete with the ability to maintain his or her proper emotional state, positively influencing the final results.

REAS/EJCH | Vol.12(1) | e1760 | DOI: https://doi.org/10.25248/reas.e1760.2020 Página 3 de 8 
Given the above, it can be seen that athletes trained by professionals from different specialties have greater abilities to deal with sports stress, as well as a substantial decrease in injuries caused by exhaustive training (VRETAROS A, 2002). Marques AT and Oliveira $J$ (2002) show in their book the correlation of high performance and success in sport with the application of scientific knowledge to the training of athletes, demonstrating that today the technical, tactical and physical preparation is no longer enough. more complex that takes care of other aspects. Among them the motor capacity of the athlete and the influence of his emotional state at the moment of exhaustion.

Thus, it becomes evident the need for the integration of the different members that make up a multidisciplinary sports team. Through this important approach in the professional relationship, it is possible to elucidate the aspects inherent to performance improvement and to maintain the athlete's performance, demonstrating a tendency towards interdisciplinarity, since the various subareas coexist (RUBIO K, 1999; VRETAROS A, 2002).

\section{Physiotherapist's Role}

The Physical Therapist is a professional movement expert in all its manifestations (prevention, rehabilitation, performance and others). It is evident that physiotherapists have a consistent generalist clinical training, which enables them to act in the care of various areas of health and at different levels of care (primary, secondary and tertiary). These professionals are empowered to intervene in disease prevention, treatment, referral and counter-referral, and in health education and promotion and high performance. From these arguments, it can easily be seen that the presence of the physiotherapist in multidisciplinary programs is of paramount importance, being the Ministry of Health itself, in this same ideology, categorical in stating that functional health is paramount at any level of health (NAVES CR and BRICK VS, 2011; DELIBERATO PCP, 2002).

The definition that reflects well the benefits of this expert's performance is put by Ragasson CAP et al. (2008) and Aveiro MC et al. (2011) referring to the fact that physiotherapy presents a primordial mission of cooperation through the new contemporary reality of health, through the application of physical therapeutic means, in the prevention, elimination or improvement of pathological or performance states, focusing its intervention on health promotion and education.

The intervention of this professional can directly benefit various sectors of society, as it is peculiar to him some activities such as: evaluation of musculoskeletal and ergonomic functions; establishment of physical therapy diagnosis; exam interpretation; prognosis achievement; prescription of therapeutic conduct; planning intervention strategies, defining objectives, conduct and procedures; participation in the development of quality of life programs and especially health education, proposing changes in lifestyle through orientation to patients, family and caregivers, treatment and training for movement improvement (AVEIRO MC, et al., 2011).

In one of the fronts of physical therapy is prevention through guidance or functional kinetic approach of temporary or permanent damage, avoiding outcomes that may imply large monetary expenses, psychological damage or decreased quality of life of the individual. There are already significant reports in the scientific literature that demonstrate the various possibilities of collective health actions promoted by this professional. It is believed that their inclusion in public health programs at the primary care level can bring great benefits to the health of society and municipal management (BAÚ LM and KLEIN KAA, 2009; RAGASSON CAP, 2008; AVEIRO MC, 2011).

\section{Role of the Physical Educator Professional}

The Physical Education Professional is a professional who specializes in physical activity in all its manifestations (gymnastics, physical exercises, games, sports, fights, dances, among others). Its purpose is to assist in the development of education and health, contributing to the acquisition and / or restoration of adequate levels of performance and fitness (DIAS JÁ, et al., 2007).

More generally, we can say that the role of the Physical Education Professional is to guide the most appropriate exercises on a case by case basis, in order to be sure that the exercise practice will promote health 
benefits. In addition, this professional has an autonomy that consists (among others) in performing actions and tasks performed. In this sense, he determines what he does and how does the selection and planning of activities, achieving his goal promoting the athlete's evolution that their health be maintained or improved (MINELLI DS, et al., 2009; RODRIGUES PAF, et al., 2014).

Roble OJ et al. (2012) discuss crucial issues regarding the effectiveness of the Physical Education Professional in the sports field. The insertion of this professional in this field is a construction of know-how, in which his / her direct action with the competitor promotes trial and error mechanisms until the expected result is reached, and in this way follows his goals in order to explore the best way. the athlete's potential enabling the improvement not only of the athlete's performance, but also of the Physical Education Professional himself as a coach.

In this trajectory, it is observed that during the training of an athlete the most recurring obstacles are the lack of full and regular technical support, coaches, fitness coaches, nutritionists and others is the lack of longterm planning and structure. In this context, the Physical Education Professional becomes the key point for the athlete's development in all phases, and with the accompaniment of this professional, the goal to which they are dedicated is hard pursued (PERES L and LOVISOLO H, 2006; VALLE MP, 2003).

Thus, Vretaros A et al. (2002), pertinently exhibit the correlation of excellence of expected result combined with knowledge and experience within a given domain which is perfectly within the capabilities of the Physical Education Professional. All this requires hard work, rigorously planned and organized, in a specialized training process, aiming at the physical, technical, tactical and psychological improvement to achieve and maintain the results. (ROSE JUNIOR D, et al., 1999).

In addition, the importance of the Physical Education Professional's performance within the sport is evidenced, showing its significant influence on the development of the athlete's individual formation, besides knowing the main strategies pointed by science for the elaboration of a safe and effective physical training (VALLE MP, 2003).

The insertion of the Physical Education professional capable of understanding the totality of body movements performed in various sports practices is fundamental in the technical sports specialty. This is because in this branch it is common to see the Physical Education Professional competing mostly with people without specific training or professionals possessing other professions. People are commonly seen working as soccer coaches, volleyball and many other sports without even having a college degree. Most of the time they are former athletes who even act as teachers in specialized roles as coach, fitness coach, coach etc (VIEIRA TP and STUCCHI S, 2007).

The arguments for Physical Education Professionals to act as technical professionals in sports are anchored in the premise that a graduate in Physical Education has knowledge of sports dimensions and the athlete inserted in this practice (VRETAROS A, et al., 2002).

The influence exerted by the sports-athlete / athlete interaction is closely linked to the individual's performance. It is important to know how to explore each athlete's point so that there is a synergism between the individual's physical capabilities with the knowledge of the Physical Education Professional in one modality (BOTH J, et al., 2018).

One more point to consider is the variables of a sports context that make evident the need for the insertion of the Physical Education Professional in the specialty of sports coach. Professional sports require skilled professionals who can see the multiple needs of the sports environment. Thus, the Physical Education Professional, can contribute with their technical-scientific ability to interact with the complex system of preparation and sports competition practices. (BALBINO HF and WINTERSTEIN PJ, 2008).

Remembering that when a Physical Education Professional acts as a coach he is working within his area of knowledge. Its formation allows the identification of relevant variables in a broad way, and thus, it is he who defines, or points out the significant needs in which he can solve or refer to another specialized professional within the multidisciplinary team (VIEIRA TP and STUCCHI S, 2007). 


\section{The Role of Different Areas in the Multidisciplinary Team}

Competitive stress is one of the most determining psychological factors for sports performance, as athletes are subjected to the most diverse competitive pressures and must vigorously overcome limits while maintaining their effectiveness and regularity in the face of the highest levels of physical demands, techniques and tactics (STEFANELLO J, 2007).

Then comes the need for psychological intervention to break down some barriers that directly interfere with performance, such as the expectation of personal effectiveness, records to overcome, overconfidence, lack of confidence, and so on. These barriers, which are often imposed by the athlete himself, can prevent even the most gifted from performing the practice to their fullest potential in sports competition (CRUZ JFA and VIANA MF, 1996).

Thus, Peres L and Lovisolo $\mathrm{H}$ (2006) recognize psychological preparation as a way of contributing to motivation, control of emotional factors, mediating relationships in the team among others.

Given the subjective regulation of this context is that psychology reflects in the athlete's training interfering directly in daily life, in the learning and performance process, as well as in the persistence capacity to overcome problems and challenges inside and outside the sport, minimizing as much as possible. the harmful interferences of the emotional aspects in the performance result (STEFANELLO J, 2007).

Entering the field of Sports Physiotherapy, Neto AG and Preis C (2005) denote this area as a promising branch of professional physical therapist activity today and is involved as a tool during the process of optimized rehabilitation of the musculoskeletal system in most sports injuries.

Importantly, high-level sports determine body patterns that go beyond the barriers of an exercise routine commonly observed in everyday life. These peculiarities result in musculoskeletal changes that are associated with the efficiency of the sports gesture, but in the long run they may evolve into morbid processes that limit the practice of regular physical activities (PERES L and LOVISOLO H., 2006).

Thus, the importance of physiotherapist follow-up in situations of training overload observed in high performance sports that cause an organic adaptation process resulting in deleterious effects for posture, with high potential for muscle imbalance (NETO JÚNIOR J, et al, 2004).

Therefore, the importance of the physiotherapist's role within the multidisciplinary sports team is revealed through the individualized clinical and functional evaluation of the athlete, collaborating with the training so that the athletes and their coaches can be oriented as to the possible muscle imbalances present and performance. biomechanics of the sport in question, thus optimizing the results and preventing injuries. (ALMEIDA C, et al., 2009).

In the area of medical activity directed at physical activity, the attention of sports medical specialists added to the rear support in the different medical specialties is important for eventual situations of greater complexity. The problems of primary and secondary care are addressed by this specialist who, in addition to clinical evaluation, requests the complementary examinations and functional evaluations that he deems necessary for the situation and after these evaluations it is up to this sector to follow up these individuals throughout their lives trainings (HERNANDEZ AJ, 2012).

Another relevant point to consider in training is the contribution of the nutritionist, since proper nutrition is an important ally for the improvement of physical performance and physical capacity and is directly related to the balanced intake of all nutrients (ALMEIDA C, et al., 2009).

In addition to improving performance, the sports nutritionist acts on the prevention factor, as there are disturbances due to failures in feeding and water, electrolyte and energy substrate replacement schemes, which greatly impair exercise tolerance and endanger the health of health practitioners. physical exercise and may even cause death (CARVALHO T and MARA LS, 2010).

Thus, nutritional monitoring becomes paramount in the athlete's performance; proper nutrition is sought to reduce injuries; improvement of energy deposits; fatigue prevention; among others. The dietitian may also 
prescribe nutritional supplements in accordance with current legislation whenever necessary, as well as perform nutrition and health education activities. Despite the importance of the nutritionist in sports, the performance of this professional is still small (STEFANELLO J, 2007).

\section{FINAL CONSIDERATIONS}

The intervention of the multidisciplinary team is a key part of a sports training. Training a team requires a correct understanding of all aspects involved, as it is a complex structure that requires the specialized work of professionals such as physician, physiotherapists, nutritionists, psychologists and Physical Education Professional. The benefit brought by the training accompanied by multidisciplinary teams enables the diagnosis of relevant points in different specialties. Moreover, it appears that these professionals acting together promote an increase in sports performance.

\section{REFERENCES}

1. ALMEIDA C, et al. Avaliação do conhecimento sobre nutrição esportiva, uso e indicação de suplementos alimentares por Profissional de Educação Física nas academias de passo fundo/RS. Revista Brasileira de Nutrição Esportiva, 2009;3(15):232-240.

2. AVEIRO MC, et al. Perspectivas da participação do fisioterapeuta no Programa Saúde da Família na atenção à saúde do idoso. Ciência \& Saúde Coletiva, 2011;16(1):1467-78.

3. BALBINO HF, WINTERSTEIN PJ. Atuação de técnicos de seleções nacionais de modalidades coletivas: elementos indicadores para um estudo sobre excelência no esporte. Revista da Faculdade de Educação Física da UNICAMP, 2008; 6:585-595,

4. BAÚ LM, KLEIN KAA. O reconhecimento da especialidade em fisioterapia do trabalho pelo COFFITO e Ministério do Trabalho/CBO: uma conquista para a fisioterapia e a saúde do trabalhador. Revista Brasileira de Fisioterapia, 2009; 13(2):5-6.

5. BOTH J, et al. Physical education teachers' wellbeing and its relation with gender. Motricidade, 2018;13(4):195-198.

6. BRANDT R. Saúde mental e fatores associados em atletas durante os jogos abertos de Santa Catarina. Revista Brasileira de Medicina do Esporte, 2014;20(4):1-5.

7. BRASIL. Conselho Federal de Educação Física. Resolução $n^{\circ}$ 046, de 18 de fevereiro de 2002. Dispõe sobre a intervenção do profissional de educação e respectivas competências e define os seus campos de atuação profissional. Conselho Federal de Educação Física. Disponível em: <http://www.confef.org.br/confef/resolucoes/82>. Acesso em: 14 out. 2017.

8. CARVALHO T, MARA LS. Hidratação e nutrição no esporte. Revista Brasileira de Medicina do Esporte, 2010;2(16):144-148.

9. CRUZ JFA, VIANA MF. Alto Confiança e Rendimento na Competição Desportiva. In: CRUZ JFA, et al. Manual de Psicologia e Desporto. 1st ed. Portugal: Lusografe - Braga, 1996; 26p.

10. DELIBERATO PCP. Fisioterapia preventiva: fundamentos e aplicações. São Paulo: Manole; 2002; 322p.

11. DIAS JÁ, et al. A Importância da Execução de Atividade Física Orientada: Uma Alternativa para o Controle de Doença Crônica na Atenção Primária. Revista Digital - Buenos Aires, 2007;12(114):1-1.

12. EPIPHANIO EH. Psicologia do Esporte: Apropriando e Desapropriação. Psicologia: Ciência e Profissão, 1999;19(3):70-73.

13. FUKUI S, et al. Effect of a multidisciplinary end-of-life educational intervention on health and social care professionals: A cluster randomized controlled trial. PLoS ONE, 2019;14(8):e0219589.

14. GOUVEIA MJM. Tendências da investigação na psicologia do desporto, exercício e atividade física. Análise Psicológica, 2001;1(19):5-14.

15. GUIMARÃES GV, CIOLAC EG. Síndrome Metabólica: Abordagem do Educador Físico. Revista da Sociedade de Cardiologia do Estado de São Paulo, 2004;14(4):659-670.

16. HERNANDEZ AJ. Perspectivas profissionais da Medicina do Esporte. Revista de Medicina, 2012;914(1):9-12.

17. LEONARDI TJ, et al. Equipe multidisciplinar e centro de treinamento do esporte de alto rendimento: estudo de caso no voleibol brasileiro. Coleção Pesquisa em Educação Física, 2016;15(3):87-94.

18. MARQUES AT, OLIVEIRA J. O treino e a competição dos mais jovens: rendimento versus saúde. In: BARBANTI VJ, et al. Esporte e atividade física: interação entre rendimento e saúde. Barueri: Manole, 2002; 368p.

19. MINELLI DS, et al. O educador físico e a intervenção em equipes multiprofissionais. Movimento. 2009;15(4):35-62.

20. MONTAGNER PC, SILVA CC. Reflexões Acerca do Treinamento a Longo Prazo e a Seleção de Talentos Através de "Peneiras" no Futebol. Revista Brasileira de Ciências do Esporte, 2003;24(2)187-200. 
21. NAVES CR, BRICK VS. Análise quantitativa e qualitativa do nível de conhecimento dos alunos do curso de fisioterapia sobre a atuação do fisioterapeuta em saúde pública. Ciência \& Saúde Coletiva, 2011;16(1):1525-1534.

22. NETO AG, PREIS C. A Valorização do Treinamento Muscular Excêntrico na Fisioterapia Desportiva. Fisioterapia em Movimento, 2005;18(1):19-26.

23. NETO JÚNIOR J, et al. Alterações posturais em atletas brasileiros do sexo masculino que participaram de provas de potência muscular em competições internacionais. Revista Brasileira de Medicina do Esporte, 2004;10(3):195198.

24. NOCE F, SIMIM MA. Análise dos fatores estressantes que interferem no rendimento do atleta ae natação no período pré-competitivo. Revista Ibero-americana de Psicología de IEjercicio y el deporte, 2009;4(1):45-58.

25. PERES L, LOVISOLO H. Formação esportiva: teoria e visões do atleta de elite no Brasil. Journal of Physical Education, 2006; 17(2):211-218.

26. PRODANOV CC, FREITAS EC. Metodologia do Trabalho Cientifico: Métodos e Técnicas da Pesquisa e do Trabalho Acadêmico. 2nd ed. Novo Hamburgo: Editora Feevale, 2013; 277p.

27. PUJALS C, VIEIRA LF. Análise dos fatores psicológicos que interferem no comportamento dos atletas de futebol de campo. Revista da Educação Física/UEM, 2002;13(1):89-97.

28. RAGASSON CAP, et al. 2008. Atribuições do fisioterapeuta no programa de saúde da família: reflexões a partir da prática profissional. In: Unioeste.

29. ROBLE OJ, et al. A educação física na saúde mental: construindo uma formação na perspectiva interdisciplinar. Interface - Comunicação, Saúde, Educação, 2012;16(41):567-577.

30. RODRIGUES PAF, et al. Centro de Referência em Obesidade do Município do Rio de Janeiro - O Papel do Educador Físico. Revista Brasileira de Atividade Física \& Saúde, 2014;19(5):656-658.

31. ROSE JUNIOR D, et al. Stressing situations in high level basketball: competitive factors. Revista Paulista de Educação Física, 1999;13(2):217-229.

32. ROSE JÚNIOR D. A competição como fonte de estresse no esporte. Revista Brasileira de Ciência do Esporte, 2002;10(4):19-26.

33. RUBIO K. A psicologia do esporte: histórico e áreas de atuação e pesquisa. Psicologia: Ciência e Profissão, 1999;19(3):60-69.

34. RUBIO K. Ética e Compromisso Social na Psicologia do Esporte. Psicologia: Ciência e Profissão, 2007;2:304-315.

35. SAMULSKI D, NOCE F. Perfil psicológico de atletas paraolímpicos brasileiros. Revista Brasileira de Medicina do Esporte, 2002;8(4):157-166.

36. STEFANELLO J. Situações de estresse no vôlei de praia de alto rendimento: um estudo de caso com uma dupla olímpica. Revista Portuguesa de Ciências do Desporto, 2007;7(2):232-244.

37. VALLE MP. O Esporte de Alto Rendimento: Produção de Atletas no Contemporâneo. In: Reunião Científica do CEAPIA. Rio Grande do Sul, 2003; 22p.

38. VIEIRA LF, et al. Estado de Humor e Desempenho Motor: Um Estudo com Atletas de Voleibol de Alto Rendimento. Revista Brasileira de Cineantropometria e Desempenho Humano, 2008;10(1):62-68.

39. VIEIRA TP, STUCCHI S. Relações Preliminares entre a Gestão Esportiva e o Educador físico. Revista da Faculdade de Educação Física da UNICAMP, 2007;5(2):113-128.

40. VRETAROS A. O papel do preparador físico no retorno à prática esportiva competitiva após reabilitação músculoesquelética: uma abordagem no tênis de campo. Revista digital - Buenos Aires, 2002;8(50):1-4. 